\title{
NECTARY STRUCTURE AND NECTAR IN SOBRALIA AND ELLEANTHUS (SOBRALIEAE: ORCHIDACEAE)
}

\author{
Kurt M. Neubig ${ }^{1,2,4}$, Barbara S. Carlsward ${ }^{3}$, W. Mark Whitten ${ }^{2}$ \\ \& NORRIS H. WiLLIAMS ${ }^{2}$ \\ ${ }^{1}$ Department of Plant Biology, Southern Illinois University of Carbondale, Carbondale, Illinois 62901 \\ ${ }^{2}$ Florida Museum of Natural History, University of Florida, Gainesville, Florida 32611 \\ ${ }^{3}$ Department of Biological Sciences, Eastern Illinois University, Charleston, Illinois 61920 \\ ${ }^{4}$ Corresponding author: kneubig@siu.edu
}

\begin{abstract}
With approximately 200 species, the tribe Sobralieae is a dominant and common Neotropical group of orchids, yet little is known of variation in floral morphology as it relates to their pollination. As currently circumscribed, the tribe includes four genera that differ considerably in flower size and morphology: Elleanthus, Epilyna, Sertifera, and Sobralia. Although nectar-foraging pollinators are known for some species, the relationships of pollination to deceit and to nectar production are all poorly understood. We examined pollination-related of nectaries and nectar characteristics (presence/absence, volume, and concentration) for major clades of Sobralieae. Some species produce abundant nectar, but many species offer no reward. When present, nectar is secreted by thickened calli at the lip base. The cells of the nectariferous calli contain starch, which is rapidly converted to sugar during a brief anthesis (often lasting only one day). Most Sobralia flowers are relatively large, bee-pollinated, with a gullet-shaped lip, false nectary, large pollinia, and offer no reward. Elleanthus flowers are relatively small with a legitimate nectar reward, and most species are hummingbirdpollinated. Hummingbird-pollinated Sobralieae flowers are relatively small, brightly colored in the perianth and/or the subtending bracts, somewhat tubular, with a lip that forms a cup around the callus for storing nectar, and pollinia that are dark and relatively small.
\end{abstract}

KeY WORDS: Deceit, Elleanthus, nectar, nectary, pollination, Sobralia, Sobralieae

Introduction. In Orchidaceae, floral rewards are extremely diverse (van der Cingel, 2001; van der Pijl and Dodson, 1966) and include nectar, oils, resin, wax, food bodies, and even fragrances (Davies and Stpiczyńska, 2008a; Whitten et al., 2007). By far, the most common reward is nectar, which is presented by flowers of varying morphology to many different pollinators: Diptera (flies), Hymenoptera (bees and wasps), Lepidoptera (moths and butterflies), Trochilidae (hummingbirds) in the New World (van der Cingel, 2001; van der Pijl and Dodson, 1966), Nectariniidae (sunbirds) (Johnson et al., 1998) and Zosteropidae (white-eyes) in the Old World (Micheneau et al., 2006).

However, it is estimated that one-third of all species of orchids use deceit strategies (Cozzolino and Widmer, 2005). This high percentage of such deceitful orchids is evidence that pollination by deceit is a successful adaptive strategy. The evolutionary forces driving deceit pollination are complex and not well understood (Jersáková et al., 2006).

In Sobralieae, known pollinators include various bees and hummingbirds. Some species produce nectar rewards, but others produce no apparent reward. Whereas food-foraging bees are attracted to flowers of diverse morphology, colors, fragrances, nectar guides, and nectar rewards, birds are attracted to nectariferous flowers with bright corollas and/or bracts of contrasting color, and that usually lack fragrances. Most investigated species of Sobralia Ruiz \& Pav. are reported to be pollinated by a variety of large solitary bees, especially by euglossine bees, whereas hummingbird pollination is known in Elleanthus C. Presl and in a few Sobralia species (Braga, 1977; Dodson, 1962, 1965; Dressler, 1971, 1976, 2002; Ducke, 1902; Dziedzioch et al., 2003; Fogden and Fogden, 2006; Roubik, 2000; 
TABLE 1. Observations of nectar secretion in this study. Although some species were observed and confirmed to have nectar, not all had measurable amounts of nectar. Only sucrose was directly measured. Volumes are in microliters $(\mu \mathrm{L})$ and concentrations are in $\%$ sucrose (sometimes noted as ${ }^{\circ} \mathrm{Bx}$ ). Additional species were sampled and produced nectar, but were too small to measure: S. ciliata, E. lancifolius, E. graminifolius, E. fractiflexus, and E. robustus.

\begin{tabular}{|c|c|c|c|c|c|c|}
\hline Species & $\begin{array}{c}\text { Sample size, } \\
\text { flowers (n) }\end{array}$ & Mean (avg) & $\begin{array}{c}\text { Standard } \\
\text { deviation }(\sigma)\end{array}$ & Range & Vouchers & Syndrome \\
\hline Elleanthus aurantiacus & 5 & & & & none (population sampling) & hummingbird \\
\hline volume & & 4.4 & 1.8 & $2-7$ & & \\
\hline concentration & & 22.8 & 1.9 & $21-26$ & & \\
\hline E. caravata & 52 & & & & Neubig 202 & hummingbird \\
\hline volume & & 5.7 & 2.4 & $2-10.1$ & & \\
\hline concentration & & 24.3 & 6.9 & $12-40$ & & \\
\hline E. cynarocephalus & 5 & & & & Neubig 247 & hummingbird \\
\hline volume & & 6 & 3.1 & $2-10$ & & \\
\hline concentration & & 9.2 & 6.6 & $5-21$ & & \\
\hline E. sodiroi & 46 & & & & Neubig 246 & hummingbird \\
\hline volume & & 13.6 & 6.5 & $4-31.5$ & & \\
\hline concentration & & 15.9 & 6.4 & $7-25$ & & \\
\hline Sobralia bouchei & 52 & & & & Blanco 3009, Neubig 208 & bee \\
\hline volume & & 14.1 & 7.9 & $2-43$ & & \\
\hline concentration & & 21.2 & 3.3 & $12-28$ & & \\
\hline S. callosa & 27 & & & & Blanco 3021, Neubig 224 & hummingbird \\
\hline volume & & 6.3 & 2.4 & $1.5-12$ & & \\
\hline concentration & & 16.3 & 2 & $12-19.5$ & & \\
\hline S. macrophylla & 6 & & & & Blanco 3022 & bee \\
\hline volume & & 4.9 & 2.4 & $1-8$ & & \\
\hline concentration & & 20.6 & 1.4 & $18-22$ & & \\
\hline S. rosea & 46 & & & & none (population sampling) & bee \\
\hline volume & & 8.4 & 8.6 & $3-35$ & & \\
\hline concentration & & 13.8 & 3.1 & $5-19.5$ & & \\
\hline
\end{tabular}

Roubik and Ackerman, 1987; Singer, 2003; van der Pij1 and Dodson, 1966). Molecular data demonstrate that Sobralia is not monophyletic (Neubig, 2012; Neubig et al., 2011), and so understanding relationships with pollinators within a phylogenetic context is critical to develop hypotheses of evolution in pollination.

The objectives of this study are to document traits of nectary structure and nectar production relative to other morphological features in Sobralia and Elleanthus and to relate these features with pollen vectors.

Materials and Methods. Observations were primarily made on cultivated plants in greenhouses of the Florida Museum of Natural History over the course of May 2007 through May 2011 and in Ecuagenera nurseries in Gualaceo, Ecuador, as well as on various natural populations in Ecuador, February 2009. Voucher specimens were deposited at FLAS and QCA herbaria. A list of taxa examined for nectar is presented in Table 1.

Nectar Volume and Quantity-. Flowers were examined for nectar presence/absence. If nectar was found, measurements were made of both volume and sucrose concentration. Sucrose concentration was measured with a 0-53 brix Atago refractometer at various times of the day, but primarily at midday and at approximately room temperature (Corbet, 2003). Concentrations are presented in percent sucrose (i.e., equivalent to Degrees Brix, g sucrose per $100 \mathrm{~g}$ solution), because 
it is a common unit used in nectar and food science (Bolten et al., 1979; Corbet, 2003; Dafni, 1992). Nectar was pipetted and measured with a $0.5-20 \mu \mathrm{L}$ Rainin micropipetter. Sugar composition and minor nectar constituents such as amino acids (Gottsberger $e t$ al., 1984) were not examined in this study.

Most plants were cultivated in a closed greenhouse, and were therefore not exposed to insects or other potential pollinators that might remove nectar. All plants of Sobralia rosea and Elleanthus aurantiacus were sampled in the wild and could therefore have had their nectar removed (thus modifying nectar volume) by visiting pollinators. Alternatively, rain could have modified nectar volume and concentration in these species. However, except for visitation by pollinators, the occurrence of such factors was the subject of careful inspection and, as far as was possible, controlled experimentation.

Floral Anatomy -. Flowers of selected species were fixed in FAA ( 9 parts $70 \%$ ethanol: 0.5 part glacial acetic acid: 0.5 part commercial formalin) for several days and stored in $70 \%$ ethanol. Floral tissues were dehydrated in a graded tertiary butanol:ethanol:water series $(6 \mathrm{~h}$ for each of the following solutions 20:50:30, 35:50:15, 55:45:0, 75:25:0, and two changes of $100 \%$ tertiary butanol). Dehydrated tissues were embedded in Paraplast ${ }^{\circledR}$ tissue embedding medium (melting point $56^{\circ} \mathrm{C}$ ) and sectioned with an American Optical 820 rotary microtome at $10 \mu \mathrm{m}$. Sections were attached to slides using Haupt's adhesive $(1 \mathrm{~g}$ gelatin: $100 \mathrm{~mL}$ water: $2 \mathrm{~g}$ phenol: $15 \mathrm{~mL}$ glycerol) and allowed to dry at $30^{\circ} \mathrm{C}$ for $12 \mathrm{~h}$. Tissues were treated in $3 \%$ ferric ammonium sulfate for $20 \mathrm{~min}$, stained in $0.5 \%$ Heidenhain's iron-alum hematoxylin for 5-10 $\mathrm{min}$, and counterstained with a $0.01 \%$ solution of safranin for $6 \mathrm{~h}$. Stained tissues were dehydrated in a graded ethanol series $(95 \%, 95 \%, 100 \%, 100 \%)$ for 5 min each and subsequently cleared in two changes of limonene. Coverslips were mounted onto slides using Permount. Observations and photographs were taken with a PixeraPro 150 es digital camera attached to a Zeiss Axioskop 40 microscope. Additional hand-cut sections were made of flowers of various species of Sobralia and Elleanthus to demonstrate variation and the presence of nectaries and cavities. Entire flowers were cleared and/or hand-sectioned, then stained with
Lugol's solution ( $\mathrm{I}_{2} \mathrm{KI}$ : iodine - potassium iodide) to test for starch. Labella of mature flowers were also hand sectioned in the morning (7 am), at noon, and in the evening $(7 \mathrm{pm})$ and stained with $\mathrm{I}_{2} \mathrm{KI}$. Hand-cut sections of fresh floral tissues were also stained with methylene blue $\left(1 \%\right.$ dissolved in $\left.\mathrm{H}_{2} \mathrm{O}\right)$ for the purpose of indicting cavities and cellular contrast.

To examine cellular detail of the surface of calli, tissues were first pickled in FAA, then dehydrated in a graded ethanol series and dried in a critical point dryer using liquid $\mathrm{CO}_{2}$. Dried samples were then mounted on clean aluminum stubs with double-sided adhesive graphite tabs. Mounted sections were coated with gold-palladium for approximately $60 \mathrm{~s}$ in an argon vacuum. Sections were photographed digitally using a Hitachi S-4000 scanning electron microscope attached to a computer utilizing Spectrum Mono software.

Results. Callus Structure -. The labellar callus is probably not homologous throughout Orchidaceae but is apparently homologous within Sobralieae. The typical callus of most Sobralia species consists of two raised ridges borne opposite each other along the length of the labellum base. When seen from the distal end of the labellum, the space between the calli forms a narrow tube (Fig. 1C), which may guide the tongue of a visiting bee, channeling it to the double cuniculus (Fig. 1D-I, see later section for definition). The calli of $S$. bouchei and $S$. callosa differ from both of the previously mentioned types. They are fused and expanded to form a pad on the median portion of the base of the labellum (Figs. 2C, H-I and 3D-H).

In Elleanthus, the callus usually consists of two relatively large, globose masses at the base of the lip (Fig. 4D-F, 5 D-E). Exceptions include E. caravata and E. robustus in which the callus is approximately the same size, but is fused into a single structure (Fig. 4D-F). All investigated species of nectariferous Sobralieae produce nectar from large stores of starch present in the callus.

Starch -. All species contained at least some starch. However, the amount of starch and the thickness of the tissue containing the starch varied. In all of the nectarsecreting species, the pad-like or globosse callus contained abundant starch. In species that produced no nectar (i.e., most species of Sobralia), the starch was less abundant, and often restricted to the epidermis of 


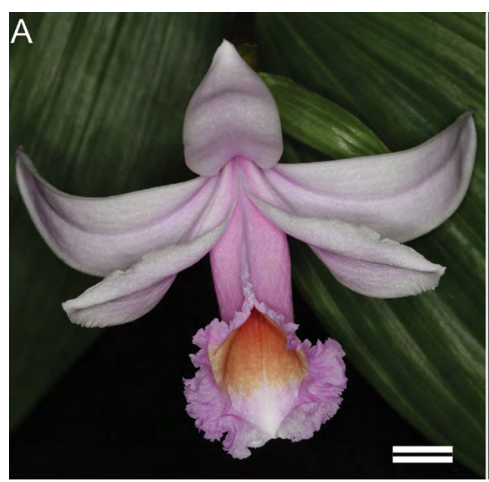

D

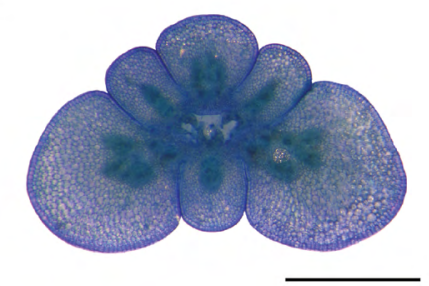

G

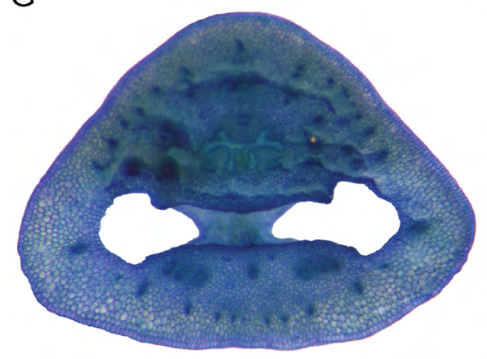

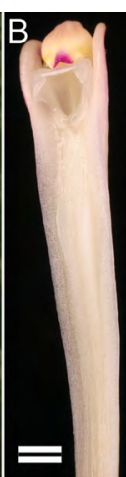

E

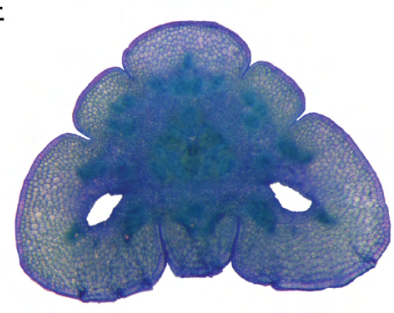

$\mathrm{H}$

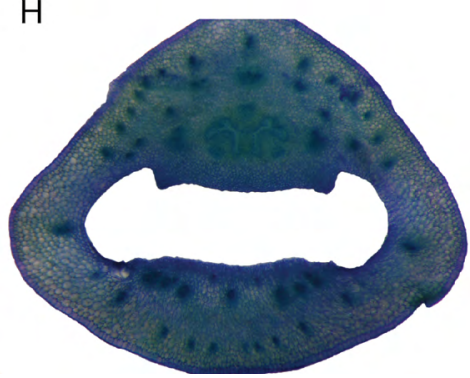

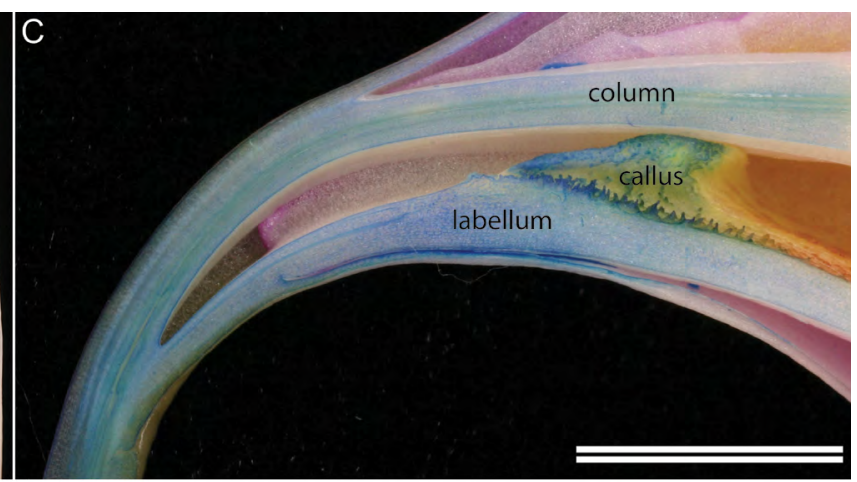

$\mathrm{F}$

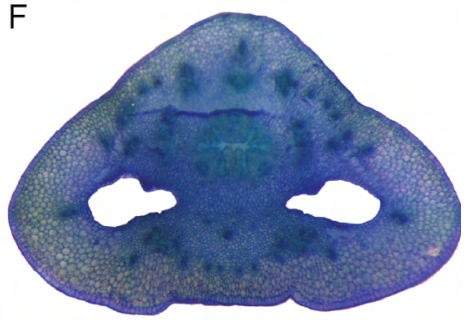

\section{I}

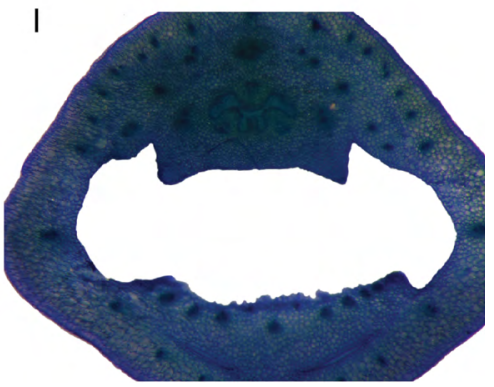

FIgURE 1. Sobralia decora (Whitten 3280) flower; a bee-pollinated flower with no nectar reward. All blue surfaces are stained with methylene blue. A. General floral morphology, scale bar $=1 \mathrm{~cm}$. B. Column showing ventral surface with a common elastic rostellum which scrapes the pollinia from the scutellum as the bee exits a flower, scale bar $=3 \mathrm{~mm}$. C. A longitudinal section of the flower, scale bar $=1 \mathrm{~cm}$. Note the long ridged callus. D-I. Serial transverse sections of the pedicel, ovary, and perianth, scale bar $=1 \mathrm{~mm}$. Note the two vacant spaces (double cuniculus) present between the sepals and the column fused to the lip; these form a pair of false nectar spurs.

the callus and epidermal trichomes. Sections of the callus made with a rotary microtome show amyloplasts that exhibited typical birefringent (cross-shaped) patterns when viewed with polarized light (Fig 5F).

Double Cuniculus -. The double cuniculus is a novel term used here to describe the paired tubes formed between the ovary and the lateral sepals. This paired, tubular, false nectary comprising a double cuniculus was found in S. chrysostoma, S. decora, S. gloriana, S. macrophylla, S. helleri, S. klotzscheana, S. powellii, $S$. warszewiczii, and $S$. sp. Species lacking a double cuniculus include $S$. bouchei, S. callosa, S. crocea, and $S$. rosea. No species of Sobralia sect. Sobralia, Elleanthus, Epilyna, or Sertifera examined has a double cuniculus.

Nectary and Nectar -. Nectar sucrose concentration and volume were measured for four species of Sobralia (S. bouchei, S. callosa, S. macrophylla, and $S$. rosea; Table 1) and four species of Elleanthus ( $E$. aurantiacus, E. caravata, E. cynarocephalus, and $E$. sodiroi; Table 1). The following species were observed to produce nectar, but the volumes produced were 

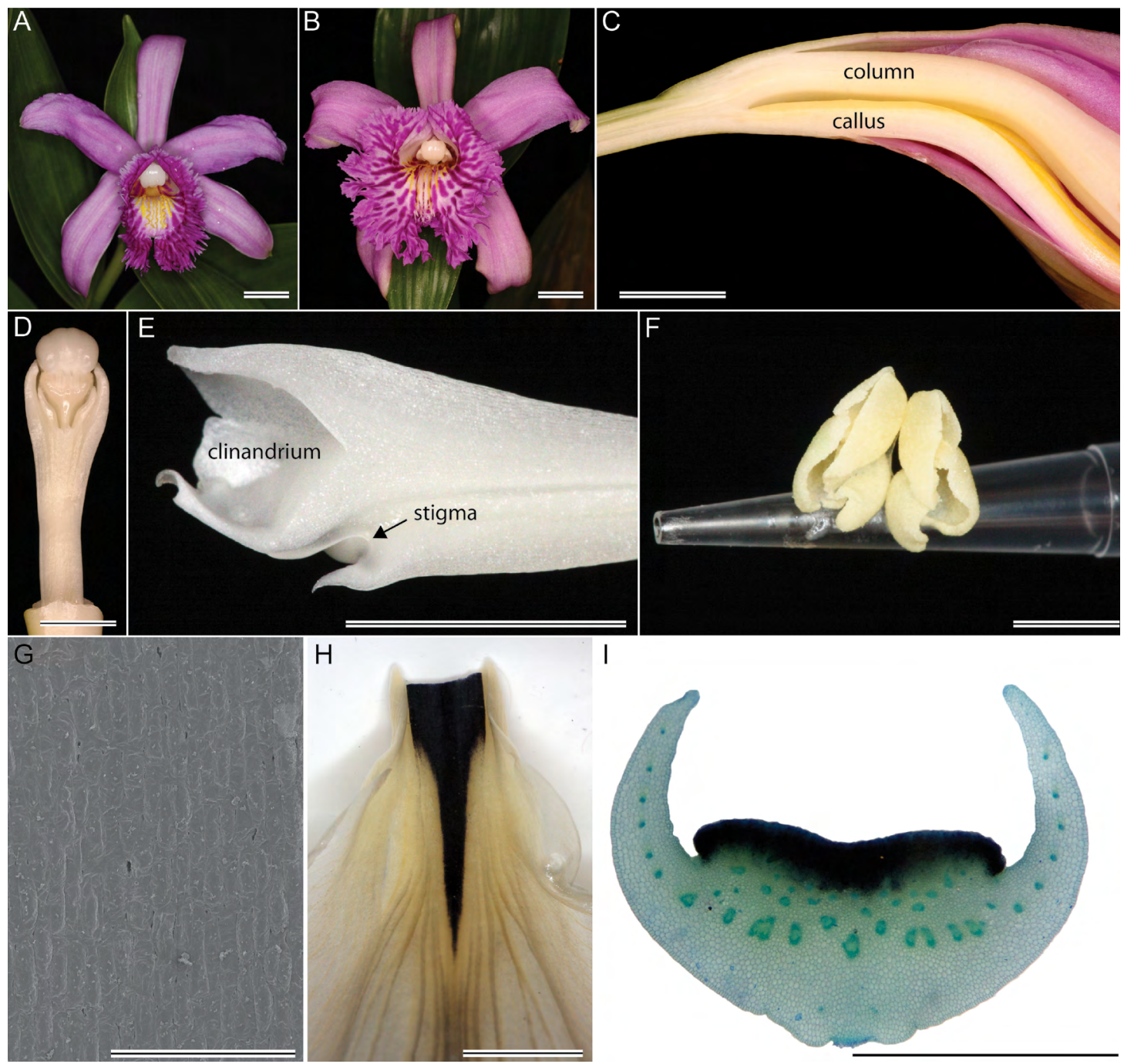

1

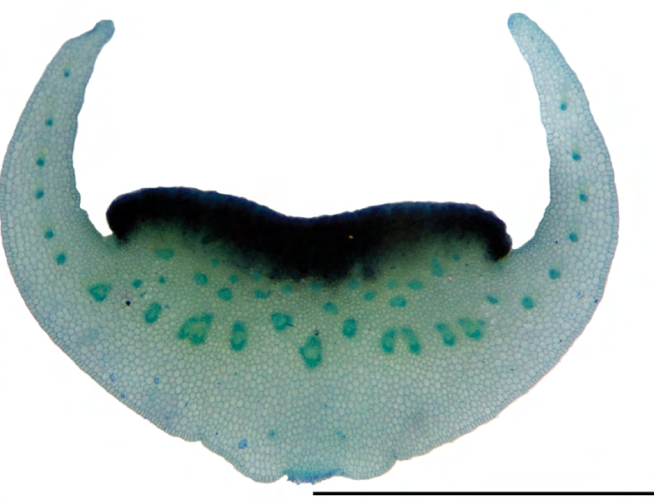

FIgURE 2. Flower of Sobralia bouchei, a bee-pollinated flower that produces nectar rewards. A. Frontal view of flower (Blanco 3009), scale bar $=1 \mathrm{~cm}$. B. Frontal view of flower (Neubig 208), scale bar $=1 \mathrm{~cm}$. C. A longitudinal section of the flower, scale bar $=1 \mathrm{~cm}$. D. Ventral view of column showing the distinctive large anther cap and slit-like stigmatic surface differing from almost all other Sobralia, scale bar $=1 \mathrm{~cm}$. E. The same column in longitudinal section with the anther removed, scale bar $=1 \mathrm{~cm}$. F. Pollinia. G. SEM of the surface of the callus of lip, showing very different cellular surface texture compared to other Sobralia species, scale bar $=1 \mathrm{~mm}$. Note the pores (intercellular spaces), which probably serve to increase surface area for nectar secretion. H. Basal portion of young lip, stained with $\mathrm{I}_{2} \mathrm{KI}$ to indicate starch, precisely outlining the callus, scale bar $=1 \mathrm{~cm}$. This starch is the putative carbohydrate source for nectar secretion. I. Transverse section of lip, showing the same callus with starch stained black from $\mathrm{I}_{2} \mathrm{KI}$ while other tissues are stained with methylene blue solution, scale bar $=0.5 \mathrm{~cm}$. This thick pad represents the fusion of the two distinct calli seen in most other members of the tribe.

too small to be measured: S. ciliata, E. lancifolius, E. graminifolius, E. fractiflexus, and E. robustus. The following species appear to lack nectar: S. andreae, S. atropubescens, S. caloglossa, S. chrysostoma, $S$. citrea, S. crispissima, S. crocea, S. decora (Fig. 1), S. dichotoma, S. doremiliae, S. exigua, S. gloriana, S. helleri, S. kerryae, S. lacerata, S. leucoxantha, $S$. lindleyana, S. macrantha, S. mandonii, S. mucronata, 

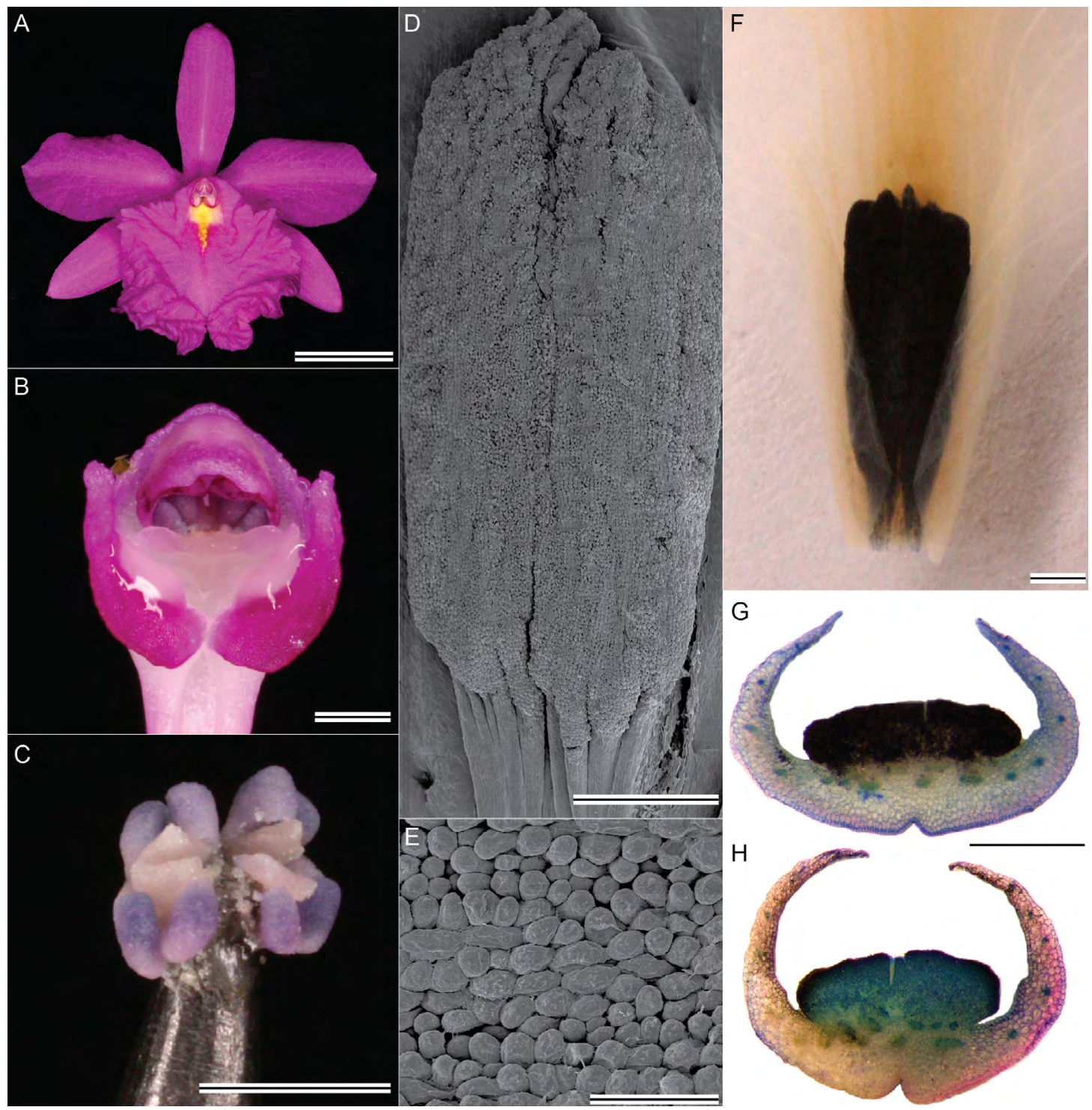

FIGURE 3. Flower of Sobralia callosa (Blanco 3021), a hummingbird-pollinated flower that produces nectar rewards. A. Frontal view of this flower, scale bar $=1 \mathrm{~cm}$. B. Frontal view of the column, scale bar $=1 \mathrm{~mm}$. Note the highly differentiated stigmatic orientation of anteriorly-facing surface which would require very different mechanical deposition during the pollination process; the pollinia would be scraped off during entry to the flower, and thus deposited on the stigma. C. Cryptic pollinia, scale bar $=1 \mathrm{~mm}$. D. SEM of the whole callus, scale bar $=1 \mathrm{~mm}$. E. Surface of the callus, showing very different cellular surface texture from $S$. bouchei (Fig. 2), scale bar $=100 \mu \mathrm{m}$. Note the extremely papillose surface texture which probably serves to increase surface area for nectar secretion. F. Basal portion of young lip, cleared, then stained with $\mathrm{I}_{2} \mathrm{KI}$ to indicate starch, precisely outlining the callus, scale bar $=1 \mathrm{~mm}$. G-H. Transverse sections of the lip and stained with $\mathrm{I}_{2} \mathrm{KI}$ to reveal starch in a young flower (morning) and an old flower (evening), respectively, showing the gradual reduction in starch over time, scale bar $=1 \mathrm{~mm}$.

S. quinata, S. recta, S. theobromina, S. violacea, $S$. warszewiczii, and $S$. yauaperyensis. The only other species of Sobralia reported to produce nectar, $S$. amabilis, was not investigated in this study. 


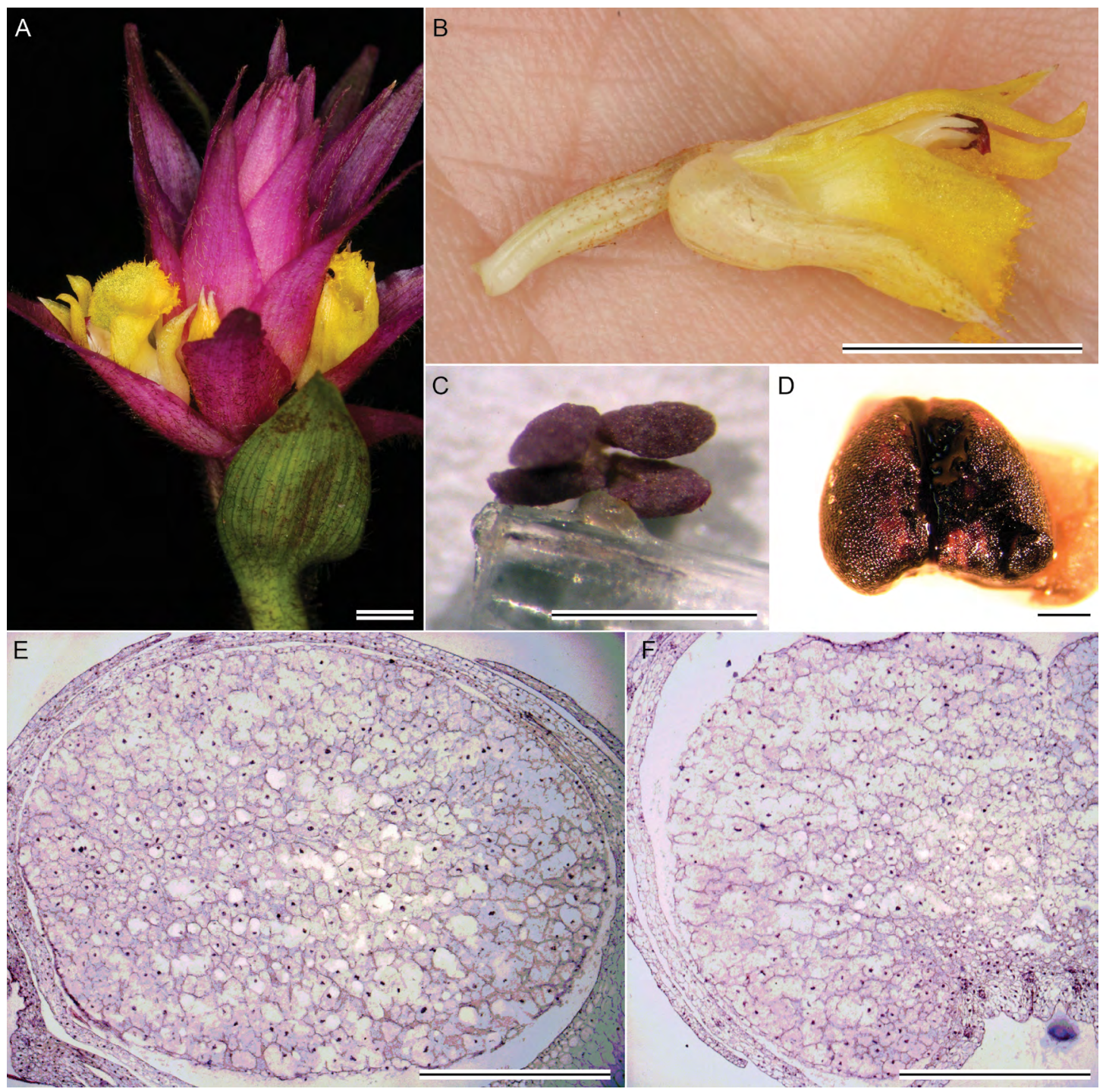

FIgURE 4. Flowers of Elleanthus caravata (Neubig 202), a hummingbird-pollinated flower that produces nectar rewards. A. Inflorescence showing the bright color contrast of bract and flower, typical of bird pollination, scale bar $=1 \mathrm{~cm}$. B. Flower showing saccate base where nectar is secreted and stored, scale bar $=1 \mathrm{~cm}$. C. Pollinia showing their relatively small size, dark color, and hard texture, scale bar $=1 \mathrm{~mm}$. D. The callus of the lip in a young flower, stained with $\mathrm{I}_{2} \mathrm{KI}$ indicating the presence of starch, scale bar $=1 \mathrm{~mm}$. E. Longitudinal section of callus, scale bar $=1 \mathrm{~mm}$. F. Transverse section of callus, scale bar $=1 \mathrm{~mm}$.

Discussion. Anatomy of floral nectaries and starch In orchids, nectar is produced in a variety of structures, including spurs or nectaries derived from the lip callus. The callus is a term given to any raised or sculptured portion of the lip. Although the callus is probably not homologous within Orchidaceae, the ability to produce thickened tissue on various floral parts may be an exaptation for secreting large amounts of a reward, either nectar or other compounds.

In all species of tribe Sobralieae, there are two calli at the base of the lip, but the calli vary in shape, size, and degree of fusion between species. Darwin (1862) first described the nectary structure of Elleanthus as large "balls", referring to the callus at the base of 


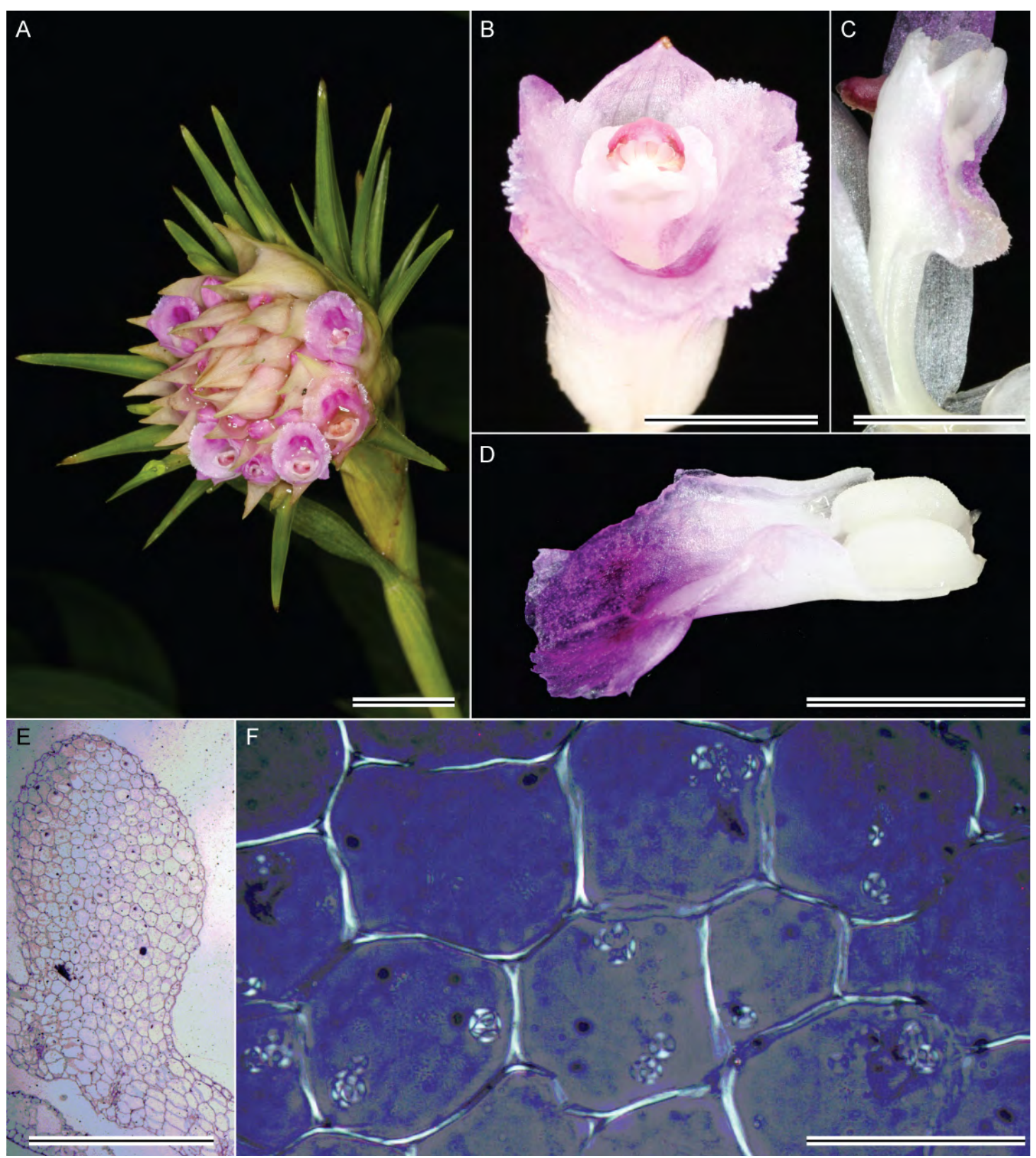

FIGURE 5. Flowers of Elleanthus sodiroi (Neubig 246) a hummingbird-pollinated flower that produces nectar rewards. A. Dense capitate inflorescence, scale bar $=1 \mathrm{~cm}$. B. Frontal view of flower showing the entrance point for the pollinator, scale bar $=0.5 \mathrm{~cm}$. C. Oblique view of ventral surface of the column, scale bar $=0.5 \mathrm{~cm}$. Note the median ridge of the column which forms a "pocket" with the lip. D. Lip of flower showing the two spherical calli at the base, scale bar $=1$ $\mathrm{cm}$. E. Transverse section of one callus, scale bar $=1 \mathrm{~mm}$. F. Transverse section of callus under polarized light, scale bar $=10 \mu \mathrm{m}$. Note the birefringent granules within each cell, indicating the presence of starch.

the labellum. Recently, the anatomy of the callus of Elleanthus brasiliensis (Lindl.) Rchb.f. was examined in detail (Nunes et al., 2013) and the callus was identified as the secretory structure. Veyret (1981), likewise, studied the floral and fruit morphology of Elleanthus and Sobralia. Veyret did not study the 
nectary structure of Elleanthus, but did study the unusual fusion of floral parts in Sobralia. In that study, a novel structure, referred to as "éperon bifide," or bifid spur, was identified in Sobralia sessilis. Our data indicate that many other species of Sobralia also have this bifid spur, which we refer to here as a double cuniculus, in reference to the very similar structure found in Epidendreae, although these structures are not homologous. The double cuniculus probably functions as a pair of parallel false nectaries or pseudo-nectaries for long-tongued insect visitors (e.g., nectar-foraging euglossine bees). No nectar was ever observed within the double cuniculus, nor is the anatomy consistent with metabolically active secretory cells.

Treatment of floral sections with $\mathrm{I}_{2} \mathrm{KI}$ (Figs. 2H-I, $3 \mathrm{~F}-\mathrm{H}, \& 4 \mathrm{D})$, as well as visualization with polarized light (Fig. 5F), revealed the distribution of starch within floral tissues. The occurrence of starch in the callus is a constant feature among all flowers in the Sobralieae; however, the quantity of the starch is variable. Even species of Sobralia that do not secrete nectar will nonetheless accumulate small amounts of starch. Furthermore, the hydrolysis of floral starch might also provide the energy for fragrance production. Those species with the greatest accumulation of starch relative to flower size produce the most nectar. Nunes et al. (2013) did not report the presence of starch in Elleanthus brasiliensis calli, but these authors may have examined old flowers with exhausted starch reserves, or possibly starch was lost during tissue manipulation. Although their flowers are relatively small compared to those of Sobralia, the calli of Elleanthus are large compared with the size of their flowers (each being approximately 2-3 $\mathrm{mm}$ long) and densely packed with starch, at least prior to anthesis. Sobralia calli were more variable both in structure and in terms of starch content. Sobralia species that produce nectar (e.g., $S$. bouchei, S. callosa, S. macrophylla, and S. rosea) have two calli that fuse together resulting in the formation of a thickened pad, which prior to anthesis, is densely packed with starch. This starch is no longer present later in the day (Fig. 3G-H) and thus, presumably, acts as a substrate both for nectar sugar production and as a source of metabolic energy for nectar secretion.

We conclude that the callus is the probable source of nectar in Sobralieae based on four observations: 1) In early stages of anthesis, droplets of nectar can be seen to form directly on the surface of the callus (and not on any other tissues); 2) All nectariferous species have starch-filled calli during the first stages of anthesis; by the onset of floral senescence, the starch is largely exhausted; 3) These calli have a dense cytoplasm that is consistent with cells that move nectar directly though the cell wall; 4) No pores or stomata with underlying vascular tissue (typical of phloem-fed nectaries) were observed on the epidermis of the callus.

A nectariferous callus has been reported in other orchids, but the frequency and distribution of such a structure within the family is poorly documented. A callus that secretes nectar has been demonstrated for Maxillariella anceps (Ames \& C. Schweinf.) M.A. Blanco \& Carnevali (Davies et al., 2005), Stenorrhynchos Rich. ex Spreng. (Galetto et al., 1997), and in some other orchid groups (Davies and Stpiczyńska, 2008a). Many orchids are known to accumulate starch for various secretory purposes relating to pollination (e.g., fragrance production in Stanhopeinae). Starch accumulation followed by depletion associated with nectar secretion also has been found in other orchids such as Scaphyglottis Poepp. \& Endl. (Stpiczyńska et al., 2005a), Acianthera Scheidw. (de Melo et al., 2010), Limodorum L. (Figueiredo and Pais, 1992), Epipactis Zinn (Pais and Figueiredo, 1994), in multiple species in subfamily Orchidoideae (Galetto et al., 1997; Stpiczyńska et al., 2005b), and among other plant families (Durkee, 1983). Based on its ubiquity, it would appear that having a fixed reserve of starch is advantageous for the rapid production of floral secretions, whether they are fragrance (Curry et al., 1991) or nectar.

The ultrastructure of floral nectaries (Fahn, 1979; Vassilyev, 2010), together with the transport and secretion of nectar (Pacini and Nepi, 2007) is generally well understood. In orchids, the anatomy of structures that secrete floral rewards (including nectaries, osmophores, elaiophores, and resin-secreting structures) has only been studied recently, and for only a small number of orchid species (Davies and Stpiczyńska, 2008a; Davies and Stpiczyńska, 2008b; Davies et al., 2005; Stpiczyńska, 2003; Stpiczyńska et al., 2003, 2005a; Stpiczyńska et al., 2010). Based on these studies, floral secretions are produced by diverse anatomical structures. The secretion of nectar onto the surface of the flower can be achieved in two 
main ways. The first is via stomata in the epidermis overlying the nectary. The second is via the cell walls of the epidermis. It is this latter method that seems to predominate in Sobralieae, because there are virtually no stomata or hairs on the nectar-secreting surface of the callus (Figs. $2 \mathrm{G} \& 3 \mathrm{D}-\mathrm{E}$ ). The epidermis of most species that we examined (except for $S$. bouchei) were highly papillose, with no intercellular spaces to increase the surface area through which secretion could occur. In S. bouchei, the callus surface, as viewed using SEM, was relatively glabrous comprising brick-shaped cells with narrow intercellular spaces (Fig. 2G).

Some orchids (Aerangis Rchb.f. and Platanthera Rich.) and non-orchids (Brassica napus L.) have the ability to reabsorb the sugars secreted in unconsumed nectar (Burquez and Corbet, 1991; Koopowitz and Marchant, 1998; Stpiczyńska, 2003). There is no evidence to support this type of reabsorption in Sobralieae.

Nectar concentration and volume -. Nectar concentration and volume are two traits that are thought to be linked to the class of pollinator (Baker and Baker, 1983). Hummingbird-pollinated flowers are thought to produce relatively large volumes of dilute nectar, whereas bee-pollinated taxa produce comparatively smaller volumes of more concentrated nectar (Bolten and Feinsinger, 1978; Hainsworth and Wolf, 1972, 1976; Pyke and Waser, 1981).

The sugar concentrations of nectar have been studied extensively for various angiosperm groups, but not for Sobralieae. Many studies have demonstrated that there are differences between the floral nectar of flowers having different pollinators. For example, the range of sucrose concentrations for solitary bee nectar is $16-50 \%$, whereas that for hummingbirds is $13-30 \%$ (Baker, 1975; Baker and Baker, 1983). These ranges tend to overlap by a considerable margin and the immediate difference occurs only in the upper range of concentrations for bees. The largest difference between pollinators is the relative ratio of sucrose-glucose and fructose, but again, there is considerable overlap.

It has been suggested that hummingbirdpollinated flowers "never" have high ratios of glucose and fructose (i.e., their nectar contains relatively high concentrations of sucrose; Baker and Baker, 1983). A relatively high ratio of sucrose was found in a broad sampling of hummingbird-pollinated plants in Costa Rica (Stiles and Freeman, 1993). Therefore, there is a substantial degree of overlap in nectar volume and its sugar concentration relative to the type of pollinator. As hummingbird pollination is often a relatively derived condition within predominantly insect-pollinated groups (Beardsley et al., 2003; Kay et al., 2005), it is reasonable to assume that hummingbirds select for a specific type of nectar. More recently, the hypothesis of nectar preferences in hummingbirds has been challenged by more recent studies (Johnson and Nicolson, 2007). Similar trends in sugar ratios, as they relate to pollinators, have also been reported for Ipomoea (Galetto and Bernardello, 2004), as well as in other plant groups (Burke et al., 2000; Galetto et al., 1998), however, these studies found no significant differences in nectar composition between plants having different pollinators. Other surveys involving many unrelated plants have shown variable nectar concentrations for hummingbird-pollinated taxa (McDade and Weeks, 2004). Similarly, our observations show that sucrose concentration in Sobralieae is highly variable and were not related to pollination syndrome (Table 1; Figs. 6). We did not analyze the sugar composition of nectar nor the ratios of the individual sugars. Nevertheless, our data revealed differences in nectar volume between pollinator classes. Many of the hummingbird-pollinated species produced smaller volumes (perhaps because each inflorescence bears numerous small flowers), generally approximately 6 $\mu \mathrm{L}$ per flower (except for E. sodiroi, which produced as much as $32 \mu \mathrm{L}$ nectar per flower). Bee-pollinated flowers, such as those of $S$. bouchei and S. rosea, produced more nectar, an average yield of 8.4-14.1 $\mu \mathrm{L}$ per flower. Conversely, $S$. macrophylla produced very little nectar, and although we examined approximately 50 flowers from several different plants $(n=6)$, only rarely was nectar observed.

The majority of documented pollinators of Sobralia are nectar-foraging euglossine bees (Apidae: Euglossini). The nectar viscosity of some euglossine bee-pollinated plants other than orchids has been studied relative to the length of the proboscis of the pollinating bee (Borrell 2005, 2006). Borrell (2007) also measured sugar concentrations from euglossine 
bee crops and from various euglossine nectar sources and found that orchid bees harvest nectars with 34\%$42 \%$ sucrose, independent of body size. Borrell (2006) speculated that long nectar spurs may be a mechanism by which flowers conserve nectar while remaining attractive to traplining bee visitors. Our analyses of Sobralia nectar produced lower values than those conducted by Borrell.

Bee-pollinated species of Sobralieae produced relatively low-viscosity nectar (i.e., S. bouchei, S. macrophylla, and S. rosea), whereas species of Sobralia having deceit strategies produced no observable nectar. A larger sampling of Sobralia species that are bee-pollinated, yet produce nectar, would be difficult, since so few species of the genus produce rewards. Nevertheless, it is likely that at least a few, hitherto unexamined species, produce nectar, and Romero (1998) has reported the occurrence of pseudopollen in S. liliastrum Lindl., suggesting that both mimicry and rewards other than nectar may occur in certain species of this genus.

Nectar Deceit -. Many orchids have "gullet flowers" that produce no nectar, e.g., Cattleya (Dressler, 1981) and Cochleanthes (Ackerman, 1983). Sobralia, like many food-deceit orchids, probably takes advantage of a general floral bauplan that is attractive to a wide variety of pollinators. This is termed generalized food deception (Jersáková et al., 2006), and the mechanism is apparently frequent and sometimes referred to as pollinator naiveté (Ackerman, 1986). Most Sobralia species exhibit generalized food deception. Food deception based on generalized foraging behavior has been demonstrated for many orchids (see Jersáková, Johnson, \& Kindlmann (2006) for a detailed list of such groups) and most Sobralia species exhibit this strategy. Narrow pollinator specificity also exists in many orchids (Schiestl and Schluter, 2009), but is not known for any pollination system found in Sobralieae.

Whether pollination is achieved by rewards or deceit, floral structural adaptation is necessary for effective pollination. Orchids have a plethora of structures for presenting nectar to pollinators, especially long-tongued insects. Some members of tribe Vandeae (especially Angraecum) have long tubular spurs (formed from an invagination of the lip) that are associated with hawk moth pollination (van der Cingel, 2001). In some orchids, a cuniculus is formed by the fusion of a hypanthium-like structure, as in the Laeliinae (e.g., Brassavola R.Br.), and forms a single tube serving much the same function as the spurs in Angraecum (Stpiczyńska et al., 2010). In several genera of Zygopetalinae, a gap at the base of the lip leads into a rolled, tubular backswept sepal that forms a false spur (Ackerman, 1983). Even though these structures may not be homologous, they all have a similar function, namely to facilitate pollination, either by deceit or through the production of a legitimate rewards. Most species of Sobralia deceive the pollinator in that they have a ridged callus that forms a tube that serves as a funnel and guides the proboscis of the pollinator deep into the "double cuniculus" embedded within the ovary (Fig. 1).

The double cuniculus is unusual among orchids and is found only in part of the core group of Sobralia (Neubig, 2012; Neubig et al., 2011). It comprises an open channel that runs between the lateral sepals and the ovary and can extend up to several centimeters into the latter (Fig. 1). This is perhaps the most significant feature of the double cuniculus. All the flowers having a double cuniculus that we examined offered no nectar reward, neither at the callus, as is typical of other Sobralieae, nor within this cunicular region, deep inside the ovary. Because Sobralia usually has a typical gullet-shaped flower (zygomorphic, with a tubular lip and nectar guides), and because it produces no nectar, this double cuniculus is interpreted as being a pair of false nectaries. This probably contributes to the effectiveness of the deceit, especially in the case of long-tongued bees, and in particular, Apidae (Danforth et al., 2006). This interpretation is supported by the fact that the width of the individual tubes of the double cuniculus exceeds the width of the proboscis of known bee pollinators (e.g., euglossines). We speculate that the deep double cuniculus induces the bee to probe further into the throat of the flower, thereby increasing the likelihood of effective pollination (Nilsson, 1988). Because long-tongued euglossine bees are the most commonly observed pollinators of Sobralia, this length-mediated deceit probably contributes significantly to pollinator selection.

Based on the fact that euglossines have the longest proboscises of any Neotropical bee subtribe, we hypothesize that any Sobralia species that possesses 
cunicular tubes that penetrate deeply into the ovary is likely to be pollinated by nectar-foraging euglossine bees (male or female). Even nectariferous species, such as Sobralia rosea, have very large flowers with a particularly long, tubular throat $(\sim 5 \mathrm{~cm})$, at the base of which occurs a true nectary favoring pollination by long-tongued bees.

Future directions -. Detailed observations of floral morphology, anatomy, and secretions cannot substitute for careful field studies of pollination biology, but they may contribute to a hypothesis that can inform and prioritize fieldwork. The most glaring gaps in our knowledge relate to plant-pollinator relationships at the species level, especially for the white-flowered species of Elleanthus sect. Elleanthus, sect. Chloidelyna, and Epilyna. Verification of hummingbird pollination in other taxa, such as Sertifera, Sobralia ciliata, $S$. callosa, and $S$. crocea, is also critical for accurate interpretation of the number of modifications to this derived pollination syndrome.

The pollinators of the small, white-flowered species of Elleanthus and Epilyna are still not known. These species include E. lancifolius (sect. Elleanthus), all of sect. Chloidelyna (e.g., E. fractiflexus, E. graminifolius, E. linifolius, E. poiformis, and E. stolonifer), E. caricoides, and all of Epilyna. These flowers are even smaller than those of typical hummingbird-pollinated species, and have no bright colors, and therefore, it is highly unlikely that they attract or can be pollinated effectively by hummingbirds. These species have yellow pollinia and very small quantities of nectar $(<1 \mu \mathrm{L})$, and it has been speculated that they are pollinated by small, nectar-seeking moths, such as
Noctuidae (C. Dodson, pers. comm.).

Most intriguing is the species $S$. rarae-avis (and the putatively closely related $S$. madisonii and $S$. infundibuligera, neither of which were examined morphologically in this study); their nocturnal fragrance is suggestive of pollination by hawkmoths or crepuscular bees, pollinator classes hitherto unknown for Sobralieae. The advent of increasingly cheap and portable digital video cameras should prove useful in documenting visits by pollinators.

By elucidating a greater number of specific plantpollinator interactions for selected clades of Sobralieae, a more fine-tuned appreciation of the evolution of pollination-related floral features might be obtained, and recent molecular phylogenetic studies can be used to provide the evolutionary context for mapping such features (Neubig, 2012; Neubig et al., 2011).

ACKNOWLEDGEMENTS. We thank Jardín Botánico Lankester (Universidad de Costa Rica) and Delsy Trujillo (USM) for contributing voucher specimens and tissue. We are grateful to the Atlanta Botanical Garden, the Portilla family of Ecuagenera Ltd. in Gualaceo, Ecuador and Andy Phillips of Andy's Orchids in Encinitas, California, for generous access to their collections. Robert Dressler contributed his detailed knowledge of Sobralieae. Mario Blanco and Lorena Endara provided many helpful discussions. Specimen curation has been provided primarily by Kent Perkins (FLAS). Parts of this research were funded by the Lewis and Varina Vaughn Fellowship in Orchid Biology, the American Orchid Society's 11th World Orchid Conference Fellowship to K. Neubig, and the U.S. National Science Foundation grant \# DEB234064 to N.H. Williams and W.M. Whitten.

\section{LITERATURE CITED}

Ackerman, J. (1983). Euglossine bee pollination of the orchid, Cochleanthes lipscombiae: a food source mimic. Am. J. Bot., $70,830-834$.

Ackerman, J. (1986). Mechanisms and evolution of food-deceptive pollination systems in orchids. Lindleyana, 1, $108-113$.

Baker, H. G. (1975). Concentrations in nectars from hummingbird flowers. Biotropica, 7, 37-41.

Baker, H. G., \& Baker, I. (1983). A brief historical review of the chemistry of floral nectar. In: B. Bentley \& T. S. Elias (Eds.), The biology of nectaries. New York: Columbia University Press.

Beardsley, P. M., Yen, A. \& Olmstead, R. G. (2003). AFLP phylogeny of Mimulus section Erythranthe and the evolution of hummingbird pollination. Evolution, 57, 1397-1410.

Bolten, A. B. \& Feinsinger, P. (1978). Why do hummingbird flowers secrete dilute nectar? Biotropica, 10, 307-309.

Bolten, A. B., Feinsinger, P., Baker, H. G. \& Baker, I. (1979). On the calculation of sugar concentration in flower nectar. Oecologia, 41, 301-304.

Borrell, B. J. (2005). Long tongues and loose niches: evolution of euglossine bees and their nectar flowers. Biotropica, 37 , $664-669$. 
Borrell, B. J. (2006). Mechanics of nectar feeding in the orchid bee Euglossa imperialis: pressure, viscosity and flow. $J$. Exp. Biol., 209, 4901-4907.

Borrell, B. J. (2007). Scaling of nectar foraging in orchid bees. Am. Nat., 169, 569-580.

Braga, P. (1977). Aspectos biologicos das Orchidaceae da Amazônica Central. Acta Amazonica, Manaus, 7, 1-89.

Burke, J. M., Wyatt, R., dePamphilis, C. W. \& Arnold, M. L. (2000). Nectar characteristics of interspecific hybrids and their parents in Aesculus (Hippocastanaceae) and Iris (Iridaceae). J. Torr. Bot. Soc., 127, 200-206.

Burquez, A., \& Corbet, S. A. (1991). Do flowers reabsorb nectar? Functional Ecology, 5, 369-379.

Corbet, S. A. (2003). Nectar sugar content: estimating standing crop and secretion rate in the field. Apidologie, 34, 1-10.

Cozzolino, S., \& Widmer, A. (2005). Orchid diversity: an evolutionary consequence of deception? Trends in Ecology and Evolution, 20, 487-494.

Curry, K. J., McDowell, L. M., Judd, W. S. \& Stern, W. L. (1991). Osmophores, floral features, and systematics of Stanhopea (Orchidaceae). Am. J. Bot., 78, 610-623.

Dafni, A. (1992). Pollination ecology: A practical approach. New York: Oxford University Press.

Danforth, B. N., Sipes, S., Fang, J. \& Brady, S. G. (2006). The history of early bee diversification based on five genes plus morphology. PNAS, 103, 15118-15123.

Darwin, C. (1862). On the various contrivances by which British and foreign orchids are fertilised by insects, and on the good effects of intercrossing. London: John Murray.

Davies, K. L. \& Stpiczyńska, M. (2008a). The anatomical basis of floral, food-reward production in Orchidaceae. In: J. Teixeira da Silva (Ed.), Floriculture, ornamental and biotechnology: advances and topical issues, V (pp. 392-406). Japan: Global Science Books.

Davies, K. L. \& Stpiczyńska, M. (2008b). Labellar micromorphology of two euglossine-pollinated orchid genera; Scuticaria Lindl. and Dichaea Lindl. Ann. Bot., 102, 805-824.

Davies, K. L., Stpiczyńska, M. \& Gregg, A. (2005). Nectar-secreting floral stomata in Maxillaria anceps Ames \& C. Schweinf. (Orchidaceae). Ann. Bot., 96, 217-227.

de Melo, M. C., Borba, E. L. \& Sousa Paiva, E. A. (2010). Morphological and histological characterization of the osmophores and nectaries of four species of Acianthera (Orchidaceae: Pleurothallidinae). Pl. Syst. Evol., 286, $141-151$.

Dodson, C. H. (1962). The importance of pollination in the evolution of the orchids of tropical America. American Orchid Society Bulletin, 31, 525-735.

Dodson, C. H. (1965). Agentes de polinización y su influencia sobre la evolución en la familia orquidacea. Perú: Universidad Nacional de la Amazonía Peruana.

Dressler, R. L. (1971). Dark pollinia in hummingbird-pollinated orchids or do hummingbirds suffer from strabismus? Am. Nat., 105, 80-83.

Dressler, R. L. (1976). How to study orchid pollination without any orchids. In: K. Senghas (Ed.), Proceedings of the 8th World Orchid Conference (pp. 534-537). Frankfurt: German Orchid Society Inc.

Dressler, R. L. (1981). The orchids: natural history and classification. Cambridge: Harvard University Press.

Dressler, R. L. (2002). The major sections or groups within Sobralia, with four new species from Panama and Costa Rica, S. crispissima, S. gloriana, S. mariannae and S. nutans. Lankesteriana, 5, 9-15.

Ducke, A. (1902). As especies Paraenses do genero Euglossa Latr. Boletim Museu Paraense, 3, 1-19.

Durkee, L. T. (1983). The ultrastructure of floral and extrafloral nectaries. In: B. Bentley \& T. S. Elias (Eds.), The biology of nectaries (pp. 1-29). New York: Columbia University Press.

Dziedzioch, C., Stevens, A. D. \& Gottsberger, G. (2003). The hummingbird plant community of tropical montane rain forest in southern Ecuador. Plant Biology, 5, 331-337.

Fahn, A. (1979). Ultrastructure of nectaries in relation to nectar secretion. Am. J. Bot., 66, 977-985.

Figueiredo, A. C. S., \& Pais, M. S. (1992). Ultrastructural aspects of the nectary spur of Limodorum abortivum (L.) Sw. (Orchidaceae). Ann. Bot., 70, 325-331.

Fogden, M., \& Fogden, P. (2006). Hummingbirds of Costa Rica. New York: Firefly Books.

Galetto, L. \& Bernardello, G. (2004). Floral nectaries, nectar production dynamics and chemical composition in six Ipomoea species (Convolvulaceae) in relation to pollinators. Ann. Bot., 94, 269-280.

Galetto, L., Bernardello, G. \& Rivera, G. L. (1997). Nectar, nectaries, flower visitors, and breeding system in five terrestrial Orchidaceae from central Argentina. Journal of Plant Research, 110, 393-403.

Galetto, L., Bernardello, G. \& Sosa, C. A. (1998). The relationship between floral nectar composition and visitors in Lycium (Solanaceae) from Argentina and Chile: what does it reflect? Flora, 193, 303-314. 
Gottsberger, G., Schrauwen, J. \& Linskens, H. F. (1984). Amino acids and sugars in nectar, and their putative evolutionary significance. Pl. Syst. Evol., 145, 55-77.

Hainsworth, F. R., \& Wolf, L. L. (1972). Crop volume, nectar concentration and hummingbird energetics. Comp. Biochem. Phys. A, 42, 359-366.

Hainsworth, F. R. \& Wolf, L. L. (1976). Nectar characteristics and food selection by hummingbirds. Oecologia, 25, 101113.

Jersáková, J., Johnson, S. D. \& Kindlmann, P. (2006). Mechanisms and evolution of deceptive pollination in orchids. Biol. Rev., 81, 219-235.

Johnson, S. D., Linder, H. P. \& Steiner, K. E. (1998). Phylogeny and radiation of pollination systems in Disa (Orchidaceae). Am. J. Bot., 85, 402-411.

Johnson, S. D. \& Nicolson, S. W. (2007). Evolutionary associations between nectar properties and specificity in bird systems. Biol. Lett., 4, 49-52.

Kay, K. M., Reeves, P. A., Olmstead, R. G. \& Schemske, D. W. (2005). Rapid speciation and the evolution of hummingbird pollination in neotropical Costus subgenus Costus (Costaceae): evidence from the nrDNA ITS and ETS sequences. Am. J. Bot., 92, 1899-1910.

Koopowitz, H. \& Marchant, T. A. (1998). Postpollination nectar reabsorption in the African epiphyte Aerangis verdickii (Orchidaceae). Am. J. Bot., 85, 508-512.

McDade, L. A., \& Weeks, J. A. (2004). Nectar in hummingbird-pollinated Neotropical plants I: patterns of production and variability in 12 species. Biotropica, 36, 196-215.

Micheneau, C., Fournel, J. \& Pailler, T. (2006). Bird pollination in an angraecoid orchid on Reunion Island (Mascarene Archipelago, Indian Ocean). Ann. Bot., 97, 965-974.

Neubig, K. M. (2012). Systematics of tribe Sobralieae (Orchidaceae): Phylogenetics, pollination, anatomy, and biogeography of a group of Neotropical orchids. Florida: Department of Biology. University of Florida.

Neubig, K. M., Whitten, M. W., Blanco, M. A., Endara, C. L., Williams, N. H. \& Koehler, S. (2011). Preliminary molecular phylogenetics of Sobralia and relatives (Orchidaceae: Sobralieae). Lankesteriana, 11, 307-317.

Nilsson, L. A. (1988). The evolution of flowers with deep corolla tubes. Nature, 334, 147-149.

Nunes, C. E. P., de M. Castro, M., Galetto, L. \& Sazima, M. (2013). Anatomy of the floral nectary of ornithophilous Elleanthus brasiliensis (Orchidaceae: Sobralieae). Bot. J. Linn. Soc., 171, 764-772.

Pacini, E. \& Nepi, M. (2007). Nectar production and presentation. In: S. W. Nicolson, M. Nepi \& E. Pacini. (Eds.), Nectaries and nectar. Holland: Springer Press.

Pais, M. S. \& Figueiredo, A. C. S. (1994). Floral nectaries from Limodorum abortivum (L.) Sw. and Epipactis atropurpurea Rafin. (Orchidaceae); ultrastructural changes in plastids during the secretory process. Apidologie, 25, 615-626.

Pyke, G. H. \& Waser, N. M. (1981). The production of dilute nectars by hummingbird and honeyeater flowers. Biotropica, $13,260-270$.

Romero, G. A. (1998). Venezuela, Orchid Paradise. Caracas: Armitano Editores.

Roubik, D. W. (2000). Deceptive orchids with Meliponini as pollinators. Pl. Syst. Evol., 222, 271-279.

Roubik, D. W. \& Ackerman, J. (1987). Long-term ecology of euglossine orchid-bees (Apidae: Euglossini) in Panama. Oecologia, 73, 321-333.

Schiestl, F. P., \& Schluter, P. M. (2009). Floral isolation, specialized pollination, and pollinator behavior in orchids. Annu. Rev. Entomol., 54, 425-446.

Singer, R. B. (2003). Orchid pollination: recent developments from Brazil. Lankesteriana, 7, 111-114.

Stiles, F. G., \& Freeman, C. E. (1993). Patterns in floral nectar characteristics of some bird-visited plant species from Costa Rica. Biotropica, 25, 191-205.

Stpiczyńska, M. (2003). Nectar resorption in the spur of Platanthera chlorantha Custer (Rchb.) Orchidaceae - structural and microautoradiographic study. Pl. Syst. Evol., 238, 119-126.

Stpiczyńska, M., Davies, K. L. \& Gregg, A. (2003). Nectary structure and nectar secretion in Maxillaria coccinea (Jacq.) L.O. Williams ex Hodge (Orchidaceae). Ann. Bot., 93, 87-95.

Stpiczyńska, M., Davies, K. L. \& Gregg, A. (2005a). Comparative account of nectary structure in Hexisea imbricata (Lindl.) Rchb.f. (Orchidaceae). Ann. Bot. 95: 749-756.

Stpiczyńska, M., Davies, K. L. \& Kaminska, M. (2010). Structure of the cuniculus nectary in Brassavola flagellaris Barb. Rodr. (Laeliinae Benth., Orchidaceae). Acta Agrobotanica, 63, 3-10.

Stpiczyńska, M., Milanesi, C., Faleri, C. \& Cresti, M. (2005b). Ultrastructure of the nectar spur of Platanthera chlorantha (Custer) Rchb. (Orchidaceae) during successive stages of nectar secretion. Acta Biologica Cracoviensia, 47, 111-119. 
van der Cingel, N. A. (2001). An atlas of orchid pollination: America, Africa, Asia and Australia. Netherlands: A. A. Balkema.

van der Pijl, L. \& Dodson, C. H. (1966). Orchid flowers: their pollination and evolution. Florida: University of Miami Press. Vassilyev, A. E. (2010). On the mechanisms of nectar secretion: revisited. Ann. Bot., 105, 349-354.

Veyret, Y. (1981). Quelques aspects du pistil et de son devenir chez quelques Sobraliinae (Orchidaceae) de Guyane. Adansonia, 3, 75-83.

Whitten, W. M., Blanco, M. A., Williams, N. H., Koehler, S., Carnevali, G., Singer, R. B., Endara, C. L. \& Neubig, K. M. (2007). Molecular phylogenetics of Maxillaria and related genera (Orchidaceae: Cymbidieae) based on combined molecular data sets. Am. J. Bot., 94, 1860-1889. 